UDC 339.7

DOI: https://doi.org/10.32782/2413-9971/2020-32-14

Sisoian Mariam

Student at Department of World Economy and International Economic Relations Odesa I. I. Mechnikov National University

Rodiona Tetyana

PhD in Economics, Senior Lecturer at Department of World Economy and International Economic Relations

Odesa I. I. Mechnikov National University

Сісоян М. М.

студент кафедри світового господарства

і міжснародних економічних відносин

Одеського національного університету імені I. І. Мечникова

Родіонова Т. А.

кандидат економічних наук,

доцент кафедри світового господарства

і міжнародних економічних відносин

Одеський національний університет імені I. I. Мечникова

\title{
ANALYSIS OF THE CURRENT STATE OF DEVELOPMENT OF THE EXTERNAL SECTOR OF THE NORTHERN EUROPEAN ECONOMIES
}

Summary. The article analyzes the state of the external sector of the economies of Northern Europe. The subject of the study is the structure and dynamics of the external sector indicators. Countries such as the Kingdom of Sweden, the Kingdom of Norway and the Republic of Finland in the period from 2015 to 2019 were selected for the study. In order to provide a generalized description of the state of the external sector of the country, it was decided to divide the analysis into more detailed parts: it was started with the country's trade balance, then moved to the assessment of the real exchange rate and the real effective exchange rate, then it was necessary to turn to the current account and financial account balance assessment, after that to estimate the overall state of the balance of payments, which, consequently, would allow to study the net international investment position of the countries, and it was necessary to conclude the work by considering the country's external debt and indicators that characterize the stability of the overall external sector. General scientific methods are used in the article: scientific abstraction, comparative method, method of analysis and synthesis, systematization and generalization, method of calculation.

Key words: external sector, balance of payments, Northern Europe, international investment position, external debt, terms of trade.

Introduction and the problem statement. The topic of the study is relevant nowadays, because foreign economic activity is playing an increasingly important role in the economies of individual countries, which cannot leave behind it certain consequences, either positive or negative. Sweden's economy is very open to foreign trade, which accounts for $91 \%$ of its GDP (2019) [4]. In 2018, Sweden was the 22nd world economy in terms of GDP (current US dollars), $32 \mathrm{nd}$ in terms of exports, and $31 \mathrm{st}$ in terms of total imports. It is the 7 th most complex economy according to the Economic Complexity Index (ECI), which characterizes the resilience of the national economy to changes in the international market, as it takes into account the diversification and uniqueness of exported goods [9]. Cars and petroleum products are among the most exported goods in Sweden $(5.9 \%$ and $5.1 \%$ respectively), followed by medicine, auto parts and telecommunications devices [7]. Cars and petroleum products are also among Sweden's most imported goods (7\% and $6 \%$ respectively). Germany is Sweden's main trading partner in terms of both imports $(17.9 \%)$ and exports $(10.6 \%)$. Norway is the second largest recipient of Swedish exports, followed by Finland, Denmark and the United States.

Norway's share of foreign trade is $72 \%$ of GDP, which is $20 \%$ less than in Sweden [4]. In 2018, Norway ranked 27th in the world in terms of GDP (current US dollars), 33rd in terms of total exports, 40th in terms of imports and it is the 34th most complex economy according to the Economic Complexity Index (ECI) [9]. Norway's main exports are oil, fresh fish without fillets and crude aluminum. Norway's main imports are cars, refined oil, and special-purpose ships. The country's main trading partners are the United Kingdom, Germany, the Netherlands, Sweden and France, and it imports most from Sweden, Germany, China, the United States and Denmark.

The Finnish economy is less dependent on the external sector than Sweden, but Norway's share is higher, as Finland's foreign trade accounts for $80 \%$ of GDP. In 2018, Finland was the 41 st largest economy in the world in terms of GDP (current US dollars), 42nd in terms of total exports, 44th in terms of imports and 10th most difficult economy according to the Economic Complexity Index (ECI) [9]. The main exported goods are refined oil, kaolin-coated paper, automobiles, sulfate chemical cellulose and large flat-rolled stainless steel. Finland's main imports are oil, cars, and refined oil. Finland exports mainly to Germany, Sweden, the United States, the Netherlands and China, and imports mainly from Germany, Russia, Sweden, the Netherlands and China.

Taking into account the above facts, the stability of the economies of the Nordic countries largely depends on the state of foreign economic relations, for this very reason, an individual country should take measures to prevent instability.

Analysis of recent research and publications. In modern literature different scientists deal with theoretical questions concerning external sector and its influence on economic growth. Some authors note that the components of foreign economic activity can be a resource of efficiency and growth, such as international trade (Md. H. Ahamad [1]), the inflow of 
foreign direct investment (R. Narula and A. Pineli [6]), flexible exchange rates, depreciated exchange rates (M. Kogid, R. Asid, J. Lily and V. Mulok [5]) and, in some cases, external debt. The country's export orientation helps to improve the balance of payments, investment provides access to international markets, creates jobs, accumulates capital, supplies technology and management skills. Given the efficient use of external debt, it can also contribute to growth, namely through the direction of productive investment with a rate of return that is higher than the interest rate on debt. But, at the same time, all these components of the external sector may adversely affect the national economies. Not all exports can contribute to economic growth equally, potential benefits are not equal for investors from different countries of origin, FDI can lead to capital outflows through profits (Rodionova T.A. [8]), excessive devaluation of the exchange rate can jeopardize financial stability of banks and the borrower's ability to repay loans, excessive amounts and inefficient external debt management can be a burden on the economy. Thus, the impact of individual indicators can be both positive and negative, which is due to the characteristics of a country.

Part of the general problem unsolved earlier. Having examined the studies of various scientists regarding the influence of the external sector on the state and development of the economies of countries, it was found that there is quite a bit of research has been carried out for the Nordic countries in this area.

The purpose of the article. An analysis of the impact of the external sector on the economic stability of Northern Europe in the current conditions of development of the world economy.

Presentation of the main material. For Sweden and Norway in 2015-2019, there has been a positive balance of trade in goods and services, in contrast to Finland, where it has had a positive sign only in 2017 and 2019 [3]. According to the dynamics of this indicator for Sweden, it could be said that its value decreased since 2015 , but in 2019 , there has been an increase of $45 \%$. Moreover, this was not due to a reduction in the value of exports, but, on the contrary, it grew and, along with exports, the value of imports of goods and services grew steadily. And the reason for the growth of the balance in 2019 is the same fact - imports began to decline.

In Norway, the dynamics of the balance is quite volatile there are sharp declines and rises, which are largely the result of fluctuations in exports, while imports of goods and services tend to grow steadily. For 2019, the trade balance in Norway decreased 3.5 times due to a reduction in exports by $11 \%$. Finland's balance, on the other hand, has been negative for almost all years. Exports of goods and services are characterized by growth year by year, as can be said for imports. But in 2019 , the value of imports decreased by $2.5 \%$, which led to a positive trade balance of the country $-\$ 1.5$ billion.

If one's try to compare the volumes of trade activities of all three countries, it can be noted that due to the trade balance, the largest flows of foreign currency go to Sweden - an average of $\$ 19$ billion per year, which is 1.3 times more than in Norway - $\$ 15$ billion, and in the case of Finland, the country loses an average of $\$ 1$ billion a year from trading activities.

Now it is necessary to explain the dynamics of the value of exports and imports of each country through the introduction of indicators such as volumes and price indices. Thus, in Sweden at the beginning of the period under review, the reason for the decline in the value of exports is precisely the reduction in volumes, rather than prices, which in 2016, by contrast, increased by $5.65 \%[2 ; 7]$. But next year, prices remain at the same level, and volumes have increased, and thus the value. That is, we can already assume that export prices are very vol- atile and do not greatly affect the volume of production and its value. For imports, it can be noted that prices increased only in 2016, which led to a reduction in the growth rate of imports of goods and services. But the following year, when prices remained the same, imports increased by $10.54 \%$.

The change in export prices in Norway is almost not correlated with its volumes, which can be explained by the fact that this indicator did not take into account the prices of ships and oil - the main exports items. But changes in prices have a significant impact on the value of exported products. Regarding imports, it can already be stated that prices have an impact on the volume of imported products, except for 2018, and the cost is affected by both prices and production volumes (volumes have a greater impact). The value of Finnish exports is affected by both changes in prices and changes in the volume of goods and services, which is typical for imports operations.

It is also possible to analyze the indicator of terms of trade, which shows the ratio of export and import prices. For example, for Sweden, the indicator for 2015-2017 was negative, i.e. terms of trade deteriorated due to an increase in import prices relative to export prices. That is why the value of Swedish exports decreased at the beginning of the period. The negative growth rate of the indicator in the case of Norway is observed in 2015-2016, after which the terms of trade for the country are improving, in 2017 the growth rate of the ratio of export prices to imports was $6.87 \%$, and in 2018 , it was $8.91 \%$. It was during these years that Norway's exports grew rapidly. A positive indicator for Finland is observed only in 2015 and 2018. In general, it can be noted that it is characterized by strong fluctuations in changes in the ratio of export and import prices.

The next thing to analyze is the ratio of commodity prices in Northern Europe and the United States using the real exchange rate (RER). The real exchange rate in Sweden between 2015 and 2019 has been growing except in 2017 [2; 4], where due to the appreciation of the national currency, the RER has decreased, despite higher inflation abroad than in Sweden.

The economic meaning of RER growth (at direct quotation) is the fact that, on the one hand, prices may rise abroad relative to prices in the home country, and on the other hand the depreciation of the national currency, and these two phenomena, in turn, lead to create more competitive conditions in international trade for the home country. For Sweden, these conditions are observed (except for 2017), i.e. over the years, Swedish goods have been more competitive in the international market than American goods. But, in practice, this does not happen, i.e. a change in the real exchange rate does not greatly affect the country's trading activities.

In the case of Norway, the RER is also more than one, as in Sweden, which is proof that Norwegian goods are cheaper than goods in the United States. The growth of RER occurs in 2018-2019, which is the result of the devaluation of the national currency against the US dollar, despite the fact that inflation in Norway was higher in those years than in the United States. That is, theoretically, by 2017, Norway's exports should have decreased and imports should have increased. And in practice, this is the case partially. For the Finnish RER, a value less than one is already observed. In 2015-2016, the value of the indicator increases (growth is due to both the depreciation of the national currency and higher inflation abroad), next year it decreases, and in 2018 it increases again and until 2019 remains in the same position. For Finland, as well as for Sweden, in practice there is no strong influence on trading activities from the real exchange rate.

Analysis of the real exchange rate makes it possible to compare the prices of the goods of the base country with one country, and in order to understand the difference between the 
terms of trade between partner countries, there is a need to refer to the real effective exchange rate (REER) [2]. Thus, in this case, an increase in the REER indicator means a loss of competitiveness of the base country in relation to its trading partners.

Thus, in Sweden during the entire period under analysis, there is a decrease in the index, i.e. goods traded by Sweden over the years were cheaper than the same goods in partner countries (Germany, Norway, Finland, Denmark, and the USA). That is, as with the real exchange rate, it turned out that Swedish goods are more competitive than in the United States, and Sweden win among the major partners countries. But, as noted earlier, the exchange rate does not have a strong impact on its foreign trade activities. For Norway, positions weakened in 2016 (8\% growth) and 2018 (0.4\% growth), so in those years Norwegian goods were more expensive than those in the UK, Germany, the Netherlands, Sweden, France, but in 2015, 2017 and 201, the situation was completely different. The conclusions also coincide with the conclusions on the real exchange rate. In Finland in 2016 (decrease of the index by $2 \%$ ) and 2018-2019 (decrease by $17.5 \%$ ), there is a strengthening of positions in relation to Germany, Sweden, the United States, the Netherlands, China and Russia. The conclusions are also identical to those provided for the dynamics of the real exchange rate of Finland.

The next step will be to consider and compare the current account balance of the Nordic countries. In case of Sweden, it can be noted that the current account balance for 2015-2019 was positive [3], the maximum value of which falls on 2019 - \$22.33. Most of this value goes to the country's trade balance. The balance of primary incomes is also positive for all years and tends to grow rapidly - almost 8 times in 2019 compared to 2015 . The main component of primary income is income from investment activities, namely from foreign direct investment. Both the balance of investment income and employee's compensation are positive, i.e. more income from residents is sent to Sweden than is exported by non-residents. But the balance of secondary income, in contrast to the primary - negative throughout the period, and the largest deficit falls on 2019 (\$-9.95 billion), but the negative balance is not due to personal transfers (their credit is more than debit), and due to other current transfers. In general, it could be concluded that Sweden is positioning itself on the international market as a net creditor.

In the current account balance of Norway, in contrast to Sweden, the main role is played not only by trade, but also by primary income for some years - 2016 and 2019 due to the strong volatility of the share of the trade balance. The balance of primary income in 2015-2017 decreased, and from 2018 begins to grow, but for all other years it is positive, primarily due to income from portfolio and other investments. And the component of employee compensation is already negative. As in the case of Sweden, the secondary income balance for the whole period is negative. Despite this, the current account in Norway is in surplus, but it is volatile precisely because of the "trade" share. However, Norway is also a net creditor in the international market, as it saves more than it invests.

Finland is very different from the previous two countries because its current account balance is in deficit. This is primarily due to the deficit in the country's trade balance (except for 2017 and 2019) and due to secondary income. Finland's primary income balance is positive in 2015-2018, where credit and debit investment income are almost at the same level, and the country is dominated by the wages of resident workers. The country's secondary account is also in deficit for all years, where the debit of government payments pre- dominates. Consequently, Finland's current account balance is in deficit, which has decreased by $73 \%$ in recent years. That is, it can be argued that Finland, unlike Sweden and Norway, is characterized by deficits in both the trade balance and the current account.

Due to the fact that the capital account is a small part of the balance of payments of the analyzed, its consideration will be absent. More attention should be paid to the analysis of the financial accounts of the Nordic countries. In the case of Sweden it could be noted that the balance of foreign direct investment for all years except 2016 in a surplus, which indicates a predominant share of investment by Swedish residents abroad than non-residents in Sweden. The maximum figure falls on 2018 ( $\$ 11.68$ billion), and in 2019 there is a sharp decline of 22 times, which was caused by the rapid growth of FDI liabilities in 2019. The balance of portfolio investments, as well as the balance of FDI, is very volatile, but in general it is positive except for 2015 and 2018. The maximum value is reached in $2019-\$ 10.88$ billion.

The dynamics of the balance of other investments does not differs from the previous two types of investments, as in 2016 there is a deficit of $\$ 19.07$ billion, and next year there is a surplus of $\$ 14.58$ billion. Sweden's financial account, not surprisingly, also fluctuates greatly. The country almost always invests more than it receives investment, but with the exception of 2016. The largest share falls on FDI, portfolio and other types of investments in some years due to the strong volatility of all three types.

Norway's FDI is much higher than Sweden's, but one common feature remains balance sheet volatility. In 2017 and 2019 , there was a deficit of FDI, which, on the one hand, was the deficit of FDI assets (Norwegian residents sold more assets abroad than they bought), and on the other hand - the rapid growth of liabilities. Portfolio investment volumes also prevail over Swedish volumes, and in this case there is a surplus balance for all years. The balance of other investments already shows that more of this type of investment is directed to Norway than it directs abroad. The financial account of the country from 2015 to 2018 is positive, but already in 2019 there is a deficit of $\$-1.13$ billion.

Finland's FDI flows are slightly higher than those of Sweden, but lower than those of Norway. The surplus balance on FDI is observed only in 2016 and 2018. The balance on portfolio investments for all years is in deficit, the greatest value of which is achieved in 2018-2019, when there was a rapid growth ( 7 times) compared to previous years with a low level of the portfolio investment balance. The most significant component of Finland's financial account goes to other investments, the balance of which is mostly in surplus. In 2019 , there was a maximum balance value of $\$ 28.4$ billion, which was caused by the growth of debt instruments of the Central Bank in assets and the growth of the deficit of liabilities of other investments (non-residents of Finland sold more assets than purchased). In contrast to neighboring countries, Finland's financial account for all years is in deficit, which averaged $\$ 9.6$ billion in 2015-2019.

Now it is necessary to describe the general state of the balance of payments of the Nordic countries. Sweden, as mentioned earlier, is a net lender on the current account balance, and it invests these accumulated funds abroad (financial account). As the current account balance is larger than the financial one, the country's balance of payments is in surplus, but with the exception of 2019 (\$-6.29 billion). The dynamics is as follows, in 2016 there was a maximum value of $\$ 4.38$ billion, but from next year the figure begins to decline. That is, until 2018, Sweden accumulated its reserves. 
As for Norway, its current account is also in surplus - a net creditor and it also directs these flows abroad, but to a greater extent than Sweden, so Norway's balance of payments for some years will be marked "_" (in 2015, 2017 - 18 years). In 2019 , the value was already more than zero, which was not due to an increase in the current account (on the contrary, there was a decrease), but the deficit value of the financial account. That is, the state of Norway's balance of payments is relatively uncertain, because it is characterized by volatility, so in some years the country's international reserves are accumulated, and in others - decreased, and the deficit is sometimes greater than the surplus.

As previously noted, the foreign economic situation in Finland differs from its neighbors, because the current account balance and financial account for all years are in short deficit. Thus, the country is a debtor on the international market, but its costs are offset by investment flows from abroad. And only due to the second component in some years, there is a surplus trade balance for Finland, namely in 2016 and 2019. In general, the balance of its balance of payments, both deficit and surplus, remains within $\$ 1$ billion.

It is now necessary to consider the international investment position [3], i.e. the balance of accumulated investments of the countries, and clearly understand whether the country is a net debtor or creditor. At the beginning of the period under review, Sweden received more investment than it invested abroad, but in the following years the deficit narrowed and turned into a surplus. That is, it is fair to say that there is a trend of constant growth of the balance, but this growth does not coincide with the dynamics of assets, because the latter, together with liabilities, are very volatile. In 2018, the growth was 5.6 times, and in 2.6 times 2019. The largest share of assets goes to portfolio investments $-41.3 \%$, FDI $-31.4 \%$ and other investments $20.6 \%$, and reserves make up only $3.4 \%$ of assets (2019). The main share of liabilities also consists of portfolio investments $48 \%$, FDI accounts for $30 \%$, and other $-18.8 \%$.

For Norway, there are already much larger volumes of net international investment position - an average of $\$ 820.8$ billion. Over the years, there has been an increase in assets, except for 2018 (a decline of 9.6\%), which was due to a decrease in portfolio investment. The following year, volumes recovered and even broke a new record of $\$ 989.5$ billion. The main component of Norway's IIP assets is portfolio investment $-72.6 \%$ and direct investment $-13.2 \%$, and reserves account for $3.5 \%$.

For Finland, the picture is quite different - the value of the international investment position lags far behind the Norwegian. If the financial account of Finland showed a deficit, but in the IIP, on the contrary, there is a surplus except for 2018 (\$-17.7 billion), and this year was characterized by rapid growth of assets, but the growth of liabilities prevailed. The main share of assets consists of portfolio investments $-42.8 \%$ and other investments $-28 \%, 1.3 \%$ of assets go to reserves - the lowest value among the three countries of Northern Europe. Liabilities also mainly consist of portfolio $(51.7 \%)$ and other investments $-25.7 \%$.

From here it could be turned to such an indicator as external debt [2]. The dynamics of Sweden's external debt in absolute terms is as follows: in 2016 there was a sharp decline by $15.4 \%$, and growth is observed only in 2018 - by $5.9 \%$ (to $\$ 911.9$ billion). In 2019 , there was another decrease to $\$ 858.1$ billion. Sweden's external debt averaged $174 \%$ of GDP over 5 years. And the largest share of the debt goes to the long-term component, because the average short-term debt is $32 \%$ of the total. On the other hand, it can be noted that the main share of external debt is accumulated by banks $(62 \%)$, and public administration accounts for 7\% [7].
Norway's foreign debt lags far behind Sweden's in absolute terms (averages $\$ 640$ billion). The maximum value of debt is reached in 2017, after which there is a constant reduction. And in relative terms, Norway's external debt (on average $165 \%$ of GDP) is almost in the same place as Sweden, which can be said about the share of short-term debt $-36 \%$. Banks account for a larger share of Norway's external debt $61 \%$, public administration $-11 \%$, FDI $-11 \%$.

Regarding Finland's external debt, it could be said that from 2014 to 2017, the rate decreased sharply (from 217\% to $181.1 \%$ of GDP), but in 2018 the ratio of external debt to GDP increased by $35 \%$, which was due to Finland's growing debt on portfolio investments, other investments and financial derivatives. And in 2019, this figure grew to $220 \%$ of GDP. Also, it can be noted that short-term external debt accounts for $74 \%$ of the country's GDP in 2019, with the maximum in $2014(86 \%)$, and the dynamics is exactly the same as the total external debt. On average for 2014-2019, the share of shortterm debt is $35 \%$ of the total.

If it observed the structure of external debt by entities [7], it could be determined that in the 3rd quarter of 2019 , $59 \%$ accounted for banks, public administration $-17 \%$, direct investment $-10 \%$, the Central Bank $-2 \%$, and other $-12 \%$ of the total external debt. Quite interesting dynamics is recognized if it observed the share of public and private external debt. Thus, until 2017, the share of the public component in Finland's GDP outweighs the share of the private. And in 2018, there were the opposite situation.

The last step in the analysis of the state of the external economic sector of Northern Europe will be a comparison of specific indicators. The first indicator is the ratio of the net international investment position to the country's GDP, the threshold value of which should be $-35 \%$. In all three countries, this requirement is met, especially in Norway, a very strong position. If the external debt to export ratio is observed, none of the countries meets the recommendations, i.e. the export volumes of the countries are too small to pay off the external debt, but in Sweden this indicator decreases from year to year. The following two indicators make it possible to estimate the size of reserves and determine whether they are able to cover the costs of imports and short-term external debt. Only in Norway the reserves cover the country's imports, but short-term debt cannot be covered by any of the economies. The ratio of the current account balance should not be less than $-2.3 \%$. This condition applies, first of all, to Finland, because the other two countries do not have a balance deficit at all, but it is also fulfilled in Finland. And the last indicator analyzes the degree of volatility of the real exchange rate compared to the last 3 years, which should not be higher or lower than $11 \%$. Thus, in Finland and Norway, this figure is within the permitted limits, which cannot be said for Sweden (12.7\% and $11.9 \%$ in 2018 and 2019 , respectively).

Conclusions. Thus, the external sector plays important role for the economies of Northern Europe, and especially for Sweden, which together with Finland is the world leader in the level of complexity of exported goods, and Norway lags far behind them, as its exports are not highly diversified and unique. The goods of all three countries have a competitive advantage over their trading partners, and changes in the real exchange rate have a strong impact on Norway's trade. Sweden and Norway are net creditors in the international market through current account surpluses, balance of payments and international investment position. Although Finland has a current account and financial account deficit, in some years its IIP is also in surplus. Exports of goods and services are insufficient to cover their external debt, as are short-term debt reserves, but Norway's reserves can cover imports of its goods and services. 


\section{References:}

1. Ahamad Md. H. (2018). Impact of International Trade on Economic Growth of Bangladesh. ResearchGate. Retrieved from: https://www.researchgate.net/publication/329277476_Impact_of_International_Trade_on_Economic_Growth_in_Bangladesh (accessed 15 August 2020).

2. CEIC DATA. Accurate Macro and MicroEconomic You Can Trust (2020). Retrieved from: https://www.ceicdata.com/en (accessed 25 August 2020).

3. International Monetary Fund (2020). Balance of Payments. URL: https://data.imf.org/?sk=7A51304B-6426-40C0-83DD-CA473CA1FD52 (accessed 23 August 2020).

4. International Monetary Fund (2020). World Economic Outlook Database. Retrieved from: https://www.imf.org/external/pubs/ft/ weo/2020/01/weodata/index.aspx (accessed 20 August 2020).

5. Kogid M., Asid R., Lily J. \& Mulok D. (2012). The Effect of Exchsne Rates on economic Growth: Empirical Testing on Nominal Versus Real. ResearchGate. Retrieved from: https://www.researchgate.net/publication/231233782_The_Effect_of_Exchange_ Rates_on_Economic_Growth_Empirical_Testing_on_Nominal_Versus_Real_The_Effect_of_Exchange_Rates_on_Economic_ Growth_Empirical_Testing_on_Nominal_Versus_Real (accessed 15 August 2020).

6. Narula R., Pineli A. (2018). Improving the Developmental Impact of Multinational Enterprises: Policy and Research Challenges. Springer. Retrieved from: https://link.springer.com/content/pdf/10.1007/s40812-018-0104-2.pdf (accessed 15 August 2020).

7. Nordea Trade Portal (2020). Retrieved from: https://www.nordeatrade.com/en/explore-new-market/sweden/trade-profile (accessed 22 August 2020).

8. Rodionova T.A. (2015) Dokhidnist inozemnykh investytsii v krainakh z rynkom, shcho formuietsia: vplyv na zovnishni dysbalansy [Foreign investment returns in emerging market countries: impact on external imbalances]. Odesa: Odessa I.I. Mechnikov National University. (in Ukrainian)

9. The Observatory of Economic Complexity (2020). Retrieved from: https://oec.world/en/profile/country/swe\#: :text=In\%20 2018\%2C\%20Sweden's\%20exports\%20per,Broadcasting\%20Equipment\%20(\%243.74B) (accessed 20 August 2020).

\section{Список використаних джерел:}

1. Md. H. Ahamad. Impact of International Trade on Economic Growth of Bangladesh. URL: https://www.researchgate.net/ publication/329277476_Impact_of_International_Trade_on_Economic_Growth_in_Bangladesh (дата звернення: 15.08.2020).

2. CEIC DATA. Accurate Macro and MicroEconomic You Can Trust. URL: $\bar{h}$ ttps://www.ceicdata.com/еn (дата звернення: 25.08.2020).

3. International Monetary Fund (2020). Balance of Payments. URL: https://data.imf.org/?sk=7A51304B-6426-40C0-83DDCA473CA1FD52 (дата звернення: 23.08.2020).

4. International Monetary Fund (2020). World Economic Outlook Database. URL: https://www.imf.org/external/pubs/ft/weo/ 2020/01/weodata/index.aspx (дата звернення: 20.08.2020).

5. Mori Kogid, Rozilee Asid, Jaratin Lily, Dullah Mulok. The Effect of Exchsne Rates on economic Growth: Empirical Testing on Nominal Versus Real. URL: https://www.researchgate.net/publication/231233782_The_Effect_of_Exchange_Rates_on_ Economic_Growth_Empirical_Testing_on_Nominal_Versus_Real_The_Effect_of_Exchange_Rates_on_Economic_Growth_ Empirical_Testing_on_Nominal_Versus_Real (дата звернення: 15.08.2020).

6. R. Narula, A. Pineli. Improving the Developmental Impact of Multinational Enterprises: Policy and Research Challenges. URL: https://link.springer.com/content/pdf/10.1007/s40812-018-0104-2.pdf (дата звернення: 15.08.2020).

7. Nordea Trade Portal. URL: https://www.nordeatrade.com/en/explore-new-market/sweden/trade-profile (дата звернення: 22.08.2020).

8. Родіонова Т.А. Дохідність іноземних інвестицій в країнах з ринком, що формується: вплив на зовнішні дисбаланси : монографія. Одеса : «Одеський національний університет імені I.I. Мечникова», 2015. 173 с.

9. The Observatory of Economic Complexity. URL: https://oec.world/en/profile/country/swe\#: :text=In\%202018\%2C\%20 Sweden's\%20exports\%20per,Broadcasting\%20Equipment\%20(\%243.74B) (дата звернення: 20.08.2020).

\section{АНАЛІЗ СУЧАСНОГО СТАНУ РОЗВИТКУ ЗОВНІШНЬОГО СЕКТОРУ ЕКОНОМІК КРАЇН ПІВНІЧНОЇ ЄВРОПИ}

Анотація. В статті аналізується стан зовнішнього сектору економік країн Північної Свропи. Для дослідження були обрані такі країни, як Королівство Швеції, Королівство Норвегії та Республіка Фінляндія, у період з 2015 по 2019 роки. 3 метою надання узагальненої характеристики стану зовнішнього сектору тої чи іншої країни, було вирішено розділити аналіз на більш детальні частини: розпочати 3 торгового балансу країни, після цього перейти до оцінки реального валютного курсу та реального ефективного валютного курсу, потім - до рахунку поточних операцій і фінансового рахунку, далі була надана оцінка загальному стану платіжного балансу, що дало змогу дослідити міжнародну інвестиційну позицію країн, завершивши роботу розглядом зовнішнього боргу країн та індикаторів, що характеризують стабільність їхніх зовнішніх секторів. Тема дослідження є актуальною на сьогоднішній день, адже зовнішньоекономічна діяльність 3 кожним роком відіграє все більш значиму роль в економіках окремих країн, яка, в свою чергу, не може не залишити за собою певні наслідки - чи то позитивні, чи негативні. Передбачається, що погіршення торгового балансу країн призведе до зменшення темпів економічного зростання, і навпаки, посилення реального обмінного курсу може збільшити безробіття в країнах, також, можуть існувати зв'язки між прямими іноземними інвестиціями, відкритістю торгівлі та економічним зростанням країн. Однак, цей вплив буде сильнішим, коли країна буде більш відкритою для зовнішньоторговельної діяльності. Волатильність обмінних курсів має негативний вплив на економічне зростання. Ефект волатильності залежить від режимів обмінних курсів та фінансової відкритості, тобто мінливість є більш шкідливою, коли країни використовують гнучкі режими обмінних курсів та, якщо вони фінансово відкриті. 3 іншого боку, зовнішній борг, що часто сприймається як негативне явище, може позитивно впливати на економічне зростання країн, якщо він буде ефективно використаний. В роботі використовуються загальнонаукові методи: наукова абстракція, порівняльний метод, метод аналізу та синтезу, систематизація та узагальнення, метод розрахунку.

Ключові слова: зовнішній сектор, платіжний баланс, Північна Європа, міжнародна інвестиційна позиція, зовнішній борг, умови торгівлі. 


\section{АНАЛИЗ СОВРЕМЕННОГО СОСТОЯНИЯ РАЗВИТИЯ ВНЕШНЕГО СЕКТОРА ЭКОНОМИК СТРАН СЕВЕРНОЙ ЕВРОПЫ}

Аннотация. В статье анализируется состояние внешнего сектора экономик стран Северной Европы. Для исследования были выбраны такие страны, как Швеция, Норвегия и Финляндия, в период с 2015 по 2019 годы. С целью предоставления обобщенной характеристики состояния внешнего сектора той или иной страны, анализ был разделен на более детальные части: обзор торгового баланса страны, оценка реального валютного курса и реального эффективного валютного курса, счета текущих операций и финансового счета, определение общего состояния платежного баланса, что позволит исследовать международную инвестиционную позицию стран, завершив работу рассмотрением внешнего долга и индикаторов, характеризующих стабильность внешнего сектора. В работе используются общенаучные методы: научная абстракция, сравнительный, метод анализа и синтеза, систематизация и обобщение, метод расчета.

Ключевые слова: внешний сектор, платежный баланс, Северная Европа, международная инвестиционная позиция, внешний долг, условия торговли. 